\title{
Pre-Dredging Physico-chemical Status of the River Niger at Onitsha Stretch, Anambra State, Nigeria
}

\author{
V. N. Arazu ${ }^{1, ~}{ }^{*}$, A. E. Ogbeib ${ }^{2}$, P. A. Okeke ${ }^{3}$ \\ ${ }^{1}$ Department of Biological Sciences, Anambra State University, Uli, Anambra State, Nigeria \\ ${ }^{2}$ Department of Animal and Environmental Biology, Faculty of Life Sciences, University of Benin, Benin City, Nigeria \\ ${ }^{3}$ Department of Fisheries and Aquaculture, Nnamdi Azikiwe University, Awka, Nigeria
}

Copyright (C) 2015 Horizon Research Publishing All rights reserved.

\begin{abstract}
A pre-dredging investigation of the physico-chemical qualities of the River Niger at the Onitsha-Urban Stretch was undertaken between January 2008 and December 2009. With the exception of the downstream station I and upstream station 5 (stations with minimal perturbations), stations 2, 3 and 4 had colossal but varied degrees of domestic, industrial, agricultural and automobile waste deposits. Of the 26 physico-chemical parameters determined, Transparency, Total Alkalinity, Conductivity, Total Dissolved Solid (TDS), Total Suspended Solid (TSS), Total Solid (TS), Depth, Nitrate, Lead, Iron and Calcium varied significantly $(\mathrm{P}<0.01)$ among the stations. Aposteriori Duncan Multiple Range test showed that Transparency was significantly $(\mathrm{P}<0.001)$ higher at station 5 than at the other stations. Total Alkalinity and Conductivity were higher in stations 2 and 3, 1 and 4 than in station 5. TDS, TSS and TS were significantly higher at stations 2, 3, 4 than in stations 1 and 5. Air and water temperatures were significantly different $(\mathrm{P}<0.05)$ across the 5 stations while $\mathrm{CO}_{2}$ was significantly higher at station 1 than others. $\mathrm{pH}$ in stations 2 and 5 is significantly higher than it is in 1, 3 and 5 . DO was higher in station 5 and 2 than the other stations. BOD was highest in stations 1 and 4 than the other three stations. The principal Component Analysis using Varimax Rotation showed that the major parameters controlling the water quality of the study area were $\mathrm{pH}$, air temperature, transparency, BOD, Dissolved Oxygen (DO), total alkalinity, conductivity, water current, phosphate and total dissolved solids (TDS).
\end{abstract}

Keywords Physico-chemical Status, Spatio-temporal Variation, River Niger

\section{Introduction}

Water bodies are known to cover about $70 \%$ of the earth's surface and function as solvent for a wide variety of chemical substances (Taylor, 2000; Gleick et al, 2008).
However, the results of human activities, influence of surrounding agricultural area, erosional run-offs from surrounding urban settlements, heavy domestic and industrial waste deposits near water banks cause water pollution and physico-chemical alterations in water conditions. Hence a good management of any aquatic habitat must encompass the knowledge of the optimum properties of water (Odum, 1959; Krest \& Anderson, 1975; Wetzel, 1990; Ogbeibu \& Oribhabor, 2002). These physico chemical parameters have considerable bearings on the life of lotic organisms (Holden, 1960; Hynes, 1970; Boyd, 1979; Williams, 1980; Swingle, 1999). Gonzalez (1997) observed that with the beginning of rainy season, water bodies overflow making them attractive foraging sites for amphibians and aquatic invertebrates (Ogbeibu \& Victor, 1989; Rosenberg \& Resh, 1993).

Earlier works on water quality include those of Holden and Green (1960) in River Sokoto, Egborge (1974,1979a) in Osun River in the West, Egborge and Sagay (1979) in Ona River in Osun State; and Ogbeibu and Victor (1989) in the Ikpoba River, Edo State.

The survey aims at providing the physico-chemical characteristics of the River Niger at Onitsha stretch before the commencement of the proposed dredging. The water quality data obtained could be used as a baseline reference point for future post-dredging study at this stretch of River Niger

\section{Description of the Study Area}

The section of River Niger under study flows through the heavily commercialized/Industrialized city of Onitsha in Onitsha South Local Government Area of Anambra State, Nigeria (Fig. 1). Geologically, the reach of the Niger River under study is made up of more resistant rocks of the basement complex. The floor is made up of alluvial sediments which include gravels, silts and light clays and loamy. The major soils are hydromorphic and alluvial sediments (Henderson-Sellers \& Gornitz, 1984; Odunuga et 
al., 2003).The vegetation is mainly riparian forest and wooded grassland. Human activities along the river and its littoral areas include fishing, peasant farming and offloading of sands. Five sampling stations were established along this stretch, considering their peculiar ecological settings, vegetation and human activities.

Station 1: (N009.06 E006.44 - Downstream) is accessed through the gate of the former National Inland Water-Ways-Complex, closely beneath the Niger Bridge. The outermost part is located about $30 \mathrm{~m}$ from the margin. Greater portion of the littoral part of the station is fairly grown with rooted aquatic macrophtes like Salvinia sp, Lemna and Ceratopteris cornuta. Not many activities go on here except few artisanal fishermen and few early morning swimmers.

Station 2: (N006.07 E006.45) Tributary of Nwangene Lake-In-Let into the River Niger. The lake is separated from the River by the road leading from main market, Onitsha to Fegge. It used to be a part of the Niger Benue River complex, prior to its isolation largely as a result of human activities. It is located about $15 \mathrm{~m}$ from the margin. Around the confluence of this lake tributary and River Niger, samplings were done. Four mighty pipes lead water below the Sokoto road bridge into River Niger. Previously, before the Nigerian Civil war, the area was known as the Ndende Market water Side Zone 1, as taxes were paid at the old buildings. It was also called the Ogbe-Ijoh market area. The substratum consists mainly of sand and light clay, to loamy in some areas. Other common sights are people defeacating, bathing, launderings, and disposals of large quantities of faeces and wastes from abattoirs, utensil washings by peasant hoteliers, and motorbike washings in fifties, by bike drivers. All these are mainly in the morning hours. There are no true aquatic macrophytes except vegetations like Spirogyra sp and
Commelina that were submerged during heavy rains. Also boats offloading sand scooped from the other side of the river, berth there in large numbers.

Station 3: (N006.08 E006.45): (A.K.A: Oseh-Okwodu Market Station): This is a boat-landing site located about 20 $\mathrm{m}$ from the margin grossly littered with various food items, especially green vegetables in very large quantities for sale to wholesalers. The bottom is an entangled mesh of roots and stems of macrophytes like Nymphaea lotus and Comelina sp. The muddy substratum has a mixture of vegetables and other decaying organic matter. It is also a heavy dumping site of wastes from market environs and domestic discharges from the catchments residential area. The semi-dry banks are flooded with insects of varied types. Defeacation by humans and foraging pigs are common sights here.

Station 4: (N006.09 E006.46) (Nkisi-Stream-In-Let): This is the Nkisi-Stream-Inlet which channels erosion water run-offs from several places into the river. It has sparse aquatic macrophytes as Commelina $\mathrm{sp}$ and spirogyra overlying both sides of the channel entering the river. The descending land space bears a large stationery cow house with heaps of dungs flowing into the channel. The station is close to the Marine Police Station and the Onitsha Prisons. It is also a navigable -boat-landing site. It has a substratum with little percentage of coarse sand, fine sand and silt.

Station 5: (N006.10 E006.46) (Upstream Station): This station is directly behind Onitsha Prisons quarters located about $27 \mathrm{~m}$ from the margin, and only accessible by boat. Hence, no activities go on there except artisanal fishing. Apart from the sparsely -rooted macrophytes, the bottom has entangled mesh of roots and stems of macrophtes as Nympheae lotus, Ceratophyllum submersun and Spirogyra $\mathrm{sp}$. The station is partially shaded.

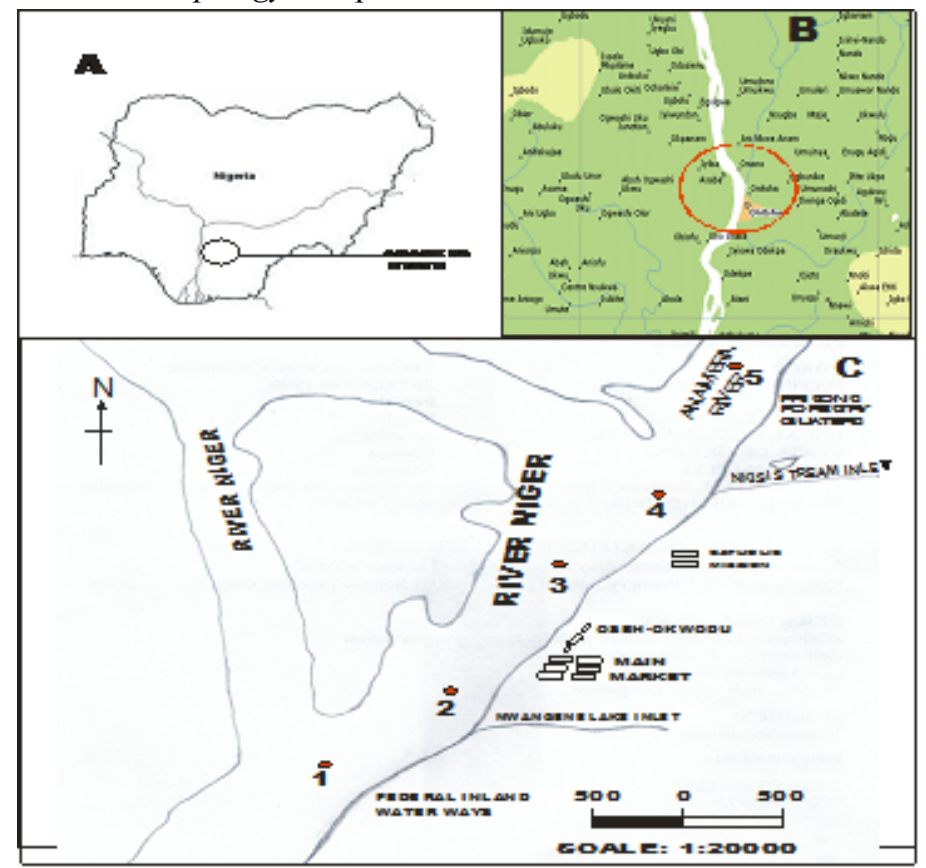

Figure 1. Map of the study area: A-Nigeria showing Anambra State, B - The major towns and cities around Onitsha, C-Sampling stations along River Niger 


\section{Materials and Methods}

The sampling period spanned from January, 2008 to December, 2009 covering both the rainy and dry seasons. Five stations were designated based on their characteristic features and sampling done on monthly basis. The water samples for the chemical analysis were collected at every station. A total of 120 samples were collected and analysed during this period.

The water level was determined at specific points in the study stations using a meter rule. Air and water temperatures were measured in-situ with mercury-in-glass thermometer, while a $20 \mathrm{~cm}$ diameter Secchi disc was used to measure transparency. $\mathrm{pH}$ and conductivity were similarly measured using $\mathrm{HACH}$ digital meter. Dissolved Oxygen (DO) and Biochemical Oxygen Demand (BOD) were estimated using Winkler's method (Boyd, 1979). The BOD was carried out after 5 days incubation at 200C. Alkalinity, phosphatephosphorous, nitrate-nitrogen and calcium were determined titrimetically following the methods in APHA (1998). Other heavy metals: chromium, copper, zinc, lead and cadmium were determined by Atomic Absorption Spectrophotometer. These metals were determined by preparing standard solutions of known metal concentrations in water. Appropriate lamp of the metal was mounted and the spectrophotometer set at the normal wavelengths and readings recorded (APHA, 1998). The Principal Components Analysis (PCA) was used to identify underlying variables, or factors, that explain the pattern of correlations within the water quality variables. The single factor analysis of variance (ANOVA) and Duncan Multiple Range (DMR) tests were used to test for significant difference among stations (Zar, 1984; Magurran, 1988; Ogbeibu, 2005). SPSS 16.0 package and PAST 1.97 were adopted.

\section{Results}

The results of the physical and chemical conditions of the study stations are summarized in Table 1 which also shows the result of Analysis of Variance (ANOVA), the statistical significance and the location of significantly different means detected by the Duncan's Multiple Range Test.

\section{Air and Water Temperature}

The range in air temperature was $20^{\circ} \mathrm{C}$ to $40{ }^{\circ} \mathrm{C}$, with a mean range of 29.30 to 30.92 while that of water was $20^{\circ} \mathrm{C}$ to $36^{\circ} \mathrm{C}$ with a mean range of 28.71 to $30.20^{\circ} \mathrm{C}$ (Table 1). The Statistical analysis using Analysis of variance (ANOVA) showed that there was no significant difference $(\mathrm{P}>0.05)$ in air and water temperature. During the study period, the mean values of both the air and water temperatures were significantly higher in wet season that during the dry season $(\mathrm{P}<0.05)$ (Table 2).
In all the stations, depth ranged from $2 \mathrm{~m}$ to $11.5 \mathrm{~m}$ with a mean range of $3.37 \mathrm{~m}$ to $7.31 \mathrm{~m}$ (Table 1). The analysis of variance showed a highly significant difference $(\mathrm{P}<0.001)$ in the depth across the 5 Stations. A posteriori Duncan Multiple Range test revealed that station 1 was significantly the deepest, while station 2 was the shallowest; stations 3, 4 and 5 were not different from one another. The mean depth was higher in the wet than in the dry season (Table 2).

In all the stations, TDS ranged from $60 \mathrm{mg} / \mathrm{l}$ (Station 1) to $471 \mathrm{mg} / 1$ (Station 4), with significant $(\mathrm{P}<0.001)$ spatial variability. A posteriori test showed that station 4 had significantly higher TDS than the other stations, while stations 1 and 5 had the lowest TDS; the others were not significantly different. The mean value of TDS was significantly higher $(\mathrm{P}<0.001)$ in wet season than in the dry season (Table 2).

The TSS ranged from $40 \mathrm{mg} / \mathrm{l}$ (station 5) to $260 \mathrm{mg} / \mathrm{l}$ (station 2), while the TS ranged from $101 \mathrm{mg} / \mathrm{l}$ (Station 5) to $642 \mathrm{mg} / \mathrm{l}$ (Stations 3 and 4). Analysis of variance showed a highly significant difference $(\mathrm{P}<0.00)$ in both the TSS and TS across the 5 stations. A posteriori test revealed that the mean values of these parameters were significantly higher in station 4 than the other stations. The mean values of TSS and TS were higher in wet season than in the dry season (Table 2).

The flow velocity was moderate in all stations, ranging from $10 \mathrm{~cm} / \mathrm{sec}$ (station 5) to $42.3 \mathrm{~cm} / \mathrm{sec}$ (station 1). The analysis of variance showed no significant difference $(\mathrm{P}>0.05)$ in the flow velocity among the stations. The mean value of flow velocity was higher in wet season (Table 2).The DMR test showed no significant difference across the five stations.

Transparency ranged from $20 \mathrm{~cm}$ stations 3 to $209 \mathrm{~cm}$ in station 1 . The analysis of variance conducted to compare mean values across the stations revealed a significant difference $(\mathrm{P}<0.05)$. A posteriori comparison showed transparency was highest in station 5 , while stations 2 and 4 had the lowest. The mean value for transparency was higher in the dry season $(102.9 \pm 30.93)$ than wet season $(80.23 \pm$ 25.84).

In all the stations, $\mathrm{pH}$ ranged from 4.10 in station 3 to 9.30 in station 5.The analysis of variance showed no significant difference $(\mathrm{P}>0.05)$ among the stations in the $\mathrm{pH}$ across the 5 stations. The mean recorded value for $\mathrm{pH}$ was higher in dry season $(6.89 \pm 0.9)$ than wet season $(6.86 \pm 0.83)$. The DMR test showed no significant difference across the five stations.

The DO ranged from $4.39 \mathrm{mg} / \mathrm{l}$ in station 3 to $9.15 \mathrm{mg} / \mathrm{l}$ in station 4 . There was no significant difference $(\mathrm{P}>0.05)$ in $\mathrm{DO}$ across the 5 stations. The mean value for DO was higher in wet season $(6.77 \pm 1.83 \mathrm{mg} / \mathrm{l})$ than dry season $(6.49 \pm$ 1.99).DMR test shows that stations 5,1 and 2 respectively which are higher in dissolved oxygen than stations 3 and 4 are not significantly different from each other. 
Table 1. Summary of the physical and chemical parameters of the river Niger at Onitsha urban-stretch (January 2008 - December 2009)

\begin{tabular}{|c|c|c|c|c|c|c|c|c|c|c|c|c|c|c|c|c|}
\hline \multirow[t]{2}{*}{ PARAMETERS } & \multicolumn{3}{|c|}{ STATION 1} & \multicolumn{3}{|c|}{ STATION 2} & \multicolumn{3}{|c|}{ STATION 3} & \multicolumn{3}{|c|}{ STATION 4} & \multicolumn{3}{|c|}{ STATION 5} & \multirow[t]{2}{*}{ P-VALUE } \\
\hline & $\bar{x} \pm$ SD & MIN & MAX & $\bar{x} \pm$ SD & MIN & MAX & $\bar{x} \pm S D$ & MIN & MAX & $\bar{x} \pm S D$ & MIN & MAX & $\bar{x} \pm$ SD & MIN & MAX & \\
\hline Air Temp ${ }^{\circ} \mathrm{C}$ & $30.92 \pm 2.93$ & 26 & 36 & $29.3 \pm 2.07$ & 24 & 33 & $30.58 \pm 2.81$ & 25 & 36 & $30.5 \pm 2.41$ & 26 & 34 & $30.75 \pm 4.04$ & 20 & 40 & $\mathrm{P}>0.05$ \\
\hline Water Temp ${ }^{\circ} \mathrm{C}$ & $28.71 \pm 2.63$ & 24 & 35 & $28.92 \pm 2.98$ & 22 & 33 & $29.04 \pm 3.30$ & 22 & 34 & $30.33 \pm 3.81$ & 20 & 36 & $28.92 \pm 4.04$ & 20 & 36 & $\mathrm{P}>0.05$ \\
\hline Depth (m) & $\begin{array}{c}7.31 \mathrm{~A} \pm 1.5 \\
2\end{array}$ & 5.35 & 11.5 & $3.37 \mathrm{C} \pm 1.07$ & 2.0 & 5.48 & $4.48 \mathrm{~B} \pm 1.76$ & 2.0 & 8.72 & $4.89 \mathrm{~B} \pm 1.52$ & 3.10 & 7.52 & $4.39 \mathrm{~B} \pm 1.67$ & 2.30 & 7.70 & $\mathrm{P}<0.001$ \\
\hline TDS (mg/l) & $\begin{array}{c}137.9 \mathrm{C} \pm 42 . \\
8\end{array}$ & 60 & 230 & $222.8 \mathrm{~B} \pm 96.5$ & 96 & 382 & $192.5 \mathrm{~B} \pm 87.0$ & 89 & 430 & $\begin{array}{c}251.2 \mathrm{~A} \pm 12 \\
3\end{array}$ & 96 & 471.2 & $126.9 \mathrm{C} \pm 54.4$ & 61 & 240 & $\mathrm{P}<0.001$ \\
\hline TSS (mg/l) & $\begin{array}{c}68.42 \mathrm{~B} \pm 11 \\
2\end{array}$ & 50.0 & 95 & $115.7 \mathrm{~A} \pm 61.2$ & 50 & 260 & $62.88 \mathrm{~B} \pm 8.50$ & 44 & 79 & $\begin{array}{c}117.5 \mathrm{~A} \pm 60 \\
5\end{array}$ & 50 & 242 & $60.17 \mathrm{~B} \pm 9.09$ & 40 & 75 & $\mathrm{P}<0.001$ \\
\hline Total Solid (mg/l) & $\begin{array}{c}206.9 \mathrm{~B} \pm 52 . \\
6\end{array}$ & 114 & 309 & $338.4 \mathrm{~A} \pm 152$ & 151 & 642 & $245.8 \mathrm{~B} \pm 101$ & 116 & 494 & $\begin{array}{c}368 \mathrm{~A} \pm 177 \\
8\end{array}$ & 175 & 642 & $189.2 \mathrm{~B} \pm 62.6$ & 101 & 323 & $\mathrm{P}<0.001$ \\
\hline Water current $(\mathbf{c m} / \mathbf{s})$ & $25.88 \pm 7.21$ & 17 & 42.3 & $22.69 \pm 7.45$ & 13.9 & 38.4 & $23.86 \pm 7.82$ & 13.9 & 40.4 & $26.28 \pm 10.3$ & 13.9 & 46.7 & $22.61 \pm 5.65$ & 10 & 30.1 & $\mathrm{P}>0.05$ \\
\hline Transparency $(\mathrm{cm})$ & $\begin{array}{c}98.88 \mathrm{~B} \pm 35 . \\
0\end{array}$ & 56 & 209 & $\begin{array}{c}81.33 \mathrm{C} \pm 26.0 \\
7\end{array}$ & 30 & 136 & $96.8 \mathrm{~B} \pm 29.5$ & 20 & 151 & $\begin{array}{c}79.71 \mathrm{C} \pm 31 \\
8\end{array}$ & 36 & 147 & $101.2 \mathrm{~A} \pm 24.7$ & 58 & 151 & $\mathrm{P}<0.05$ \\
\hline pH & $6.36 \pm 0.59$ & 5.14 & 7.70 & $7.32 \pm 0.66$ & 5.80 & 9.0 & $6.69 \pm 0.73$ & 4.10 & 8.20 & $6.82 \pm 0.93$ & 5.38 & 9.2 & $7.18 \pm 1.13$ & 5.1 & 9.30 & $\mathrm{P}<0.01$ \\
\hline DO(mg/l) & $\begin{array}{c}7.14 \mathrm{~A} \pm 1.6 \\
1\end{array}$ & 5.3 & 11.2 & $6.82 \mathrm{~A} \pm 2.00$ & 4.45 & 12.5 & $6.09 \mathrm{~B} \pm 1.78$ & 4.39 & 10.1 & $5.63 \mathrm{~B} \pm 1.19$ & 4.63 & 9.15 & $7.48 \mathrm{~A} \pm 2.32$ & 5.50 & 14.1 & $\mathrm{P}<0.01$ \\
\hline BOD (mg/l) & $\begin{array}{c}5.32 \mathrm{~A} \pm 1.4 \\
5\end{array}$ & 3.0 & 9.5 & $5.10 \mathrm{~A} \pm 1.24$ & 3.0 & 8.01 & $4.40 \mathrm{~B} \pm 1.28$ & 2.7 & 8.26 & $4.30 \mathrm{~B} \pm 1.85$ & 2.0 & 9.3 & $3.69 \mathrm{C} \pm 1.11$ & 1.8 & 5.7 & $\mathrm{P}<0.01$ \\
\hline Conductivity $(\mu \mathrm{S} / \mathrm{cm}$ & $\begin{array}{c}113.4 \mathrm{~B} \pm 15 . \\
6\end{array}$ & 80.4 & 140.6 & $128.4 \mathrm{~A} \pm 35.8$ & 80.0 & 190 & $121.7 \mathrm{~A} \pm 39.4$ & 63.3 & 183 & $\begin{array}{c}106.7 \mathrm{~B} \pm 26 \\
7\end{array}$ & 76.3 & 160 & $96.4 \mathrm{C} \pm 10.66$ & 71.5 & 116 & $\mathrm{P}<0.01$ \\
\hline $\begin{array}{c}\text { Total } \\
\text { Alkalinity(mg/l) }\end{array}$ & $\begin{array}{c}33.15 \mathrm{~B} \pm 9.0 \\
1\end{array}$ & 19.5 & 48.1 & $39.75 \mathrm{~A} \pm 10.9$ & 21.7 & 58.6 & $35.17 \mathrm{~A} \pm 10.3$ & 19.8 & 52.0 & $33.2 \mathrm{~B} \pm 9.02$ & 19.8 & 50.8 & $29.03 \mathrm{C} \pm 6.31$ & 21.1 & 40.1 & $\mathrm{P}<0.01$ \\
\hline $\mathrm{CO}_{2}(\mathrm{mg} / \mathrm{l})$ & $2.99 \mathrm{~A} \pm .59$ & 2.10 & 4.22 & $3.08 \mathrm{~A} \pm 0.35$ & 2.50 & 3.70 & $2.85 \mathrm{~A} \pm 0.51$ & 1.80 & 3.56 & $2.84 \mathrm{~A} \pm 0.35$ & 2.29 & 3.50 & $2.55 \mathrm{~B} \pm 0.28$ & 2.0 & 3.02 & $\mathrm{P}<0.01$ \\
\hline Sulphate(mg/l) & $\begin{array}{c}0.36 \mathrm{~A} \pm 0.0 \\
6\end{array}$ & 0.20 & 0.50 & $0.39 \mathrm{~A} \pm 0.19$ & 0.20 & 0.98 & $0.26 \mathrm{C} \pm 0.06$ & 0.18 & 0.40 & $0.32 \mathrm{~B} \pm 0.05$ & 0.25 & 0.45 & $0.33 \mathrm{~B} \pm 0.05$ & 0.22 & 0.40 & $\mathrm{P}<0.001$ \\
\hline Nitrate(mg/l) & $1.73 \pm 1.40$ & 0.20 & 4.71 & $1.92 \pm 1.42$ & 0.14 & 4.7 & $1.65 \pm 1.63$ & 0.13 & 5.46 & $1.60 \pm 1.42$ & 0.10 & 4.50 & $1.61 \pm 1.57$ & 0.15 & 5.30 & $\mathrm{P}>0.05$ \\
\hline Phosphate(mg/l) & $\begin{array}{c}0.36 \mathrm{~A} \pm 0.1 \\
6\end{array}$ & 0.21 & 0.90 & $0.34 \mathrm{~A} \pm 0.09$ & 0.24 & 0.70 & $0.41 \mathrm{~A} \pm 0.13$ & 0.30 & 0.90 & $0.38 \mathrm{~A} \pm 0.17$ & 0.18 & 0.90 & $0.27 \mathrm{~B} \pm 0.05$ & 0.18 & 0.37 & $\mathrm{P}<0.01$ \\
\hline Sodium(mg/l) & $0.89 \pm 0.21$ & 0.10 & 1.12 & $1.21 \pm 0.26$ & 0.85 & 1.60 & $1.21 \pm 0.22$ & 0.90 & 1.61 & $3.25 \pm 12.1$ & 0.41 & 0.60 & $0.76 \pm 0.09$ & 0.6 & 0.93 & $\mathrm{P}>0.05$ \\
\hline Potassium(mg/l) & $0.63 \mathrm{~B} \pm 0.14$ & 0.40 & 0.82 & $0.89 \mathrm{~A} \pm 0.21$ & 0.50 & 1.30 & $0.83 \mathrm{~A} \pm 0.09$ & 0.62 & 1.0 & $0.52 \mathrm{C} \pm 0.14$ & 0.10 & 0.85 & $0.51 \mathrm{C} \pm 0.09$ & 0.30 & 0.70 & $\mathrm{P}<0.001$ \\
\hline Calcium(mg/l) & $1.39 \mathrm{~B} \pm 0.48$ & 0.60 & 1.93 & $2.08 \mathrm{~A} \pm 0.76$ & 0.80 & 3.2 & $2.03 \mathrm{~A} \pm 0.73$ & 0.70 & 2.98 & $1.18 \mathrm{~B} \pm 0.41$ & 0.38 & 1.80 & $1.15 \mathrm{~B} \pm 0.38$ & 0.60 & 1.70 & $\mathrm{P}<0.001$ \\
\hline $\operatorname{Magnesium(mg/l)}$ & $3.56 \pm 1.39$ & 2.09 & 7.0 & $4.72 \pm 1.99$ & 2.90 & 9.25 & $3.97 \pm 2.19$ & 2.10 & 9.90 & $3.08 \pm 1.67$ & 1.0 & 8.55 & $3.83 \pm 2.56$ & 1.0 & 9.99 & $\mathrm{P}>0.05$ \\
\hline $\operatorname{Chromium}(\mathrm{mg} / \mathrm{l})$ & $0.12 \pm 0.15$ & 0.01 & 0.60 & $0.19 \pm 0.25$ & 0.00 & 1.0 & $0.06 \pm 0.03$ & 0.01 & 0.12 & $0.12 \pm 0.19$ & 0.00 & 1.0 & $0.10 \pm 0.19$ & 0.00 & 1.00 & $\mathrm{P}>0.05$ \\
\hline Copper(mg/l) & $0.52 \mathrm{~B} \pm .15$ & 0.6 & 0.70 & $1.27 \mathrm{~A} \pm 1.62$ & 0.12 & 0.8 & $0.65 \mathrm{~B} \pm .19$ & 0.10 & 0.90 & $0.55 \mathrm{~B} \pm 0.23$ & 0.10 & 0.90 & $0.34 \mathrm{~B} \pm 0.21$ & 0.09 & 0.90 & $\mathrm{P}<0.01$ \\
\hline Zinc(mg/l) & $2.29 \mathrm{C} \pm 1.50$ & 0.40 & 5.85 & $4.01 \mathrm{~A} \pm 1.89$ & 1.22 & 9.20 & $4.58 \mathrm{~A} \pm 2.23$ & 1.52 & 9.01 & $3.26 \mathrm{~B} \pm 2.27$ & 1.0 & 9.45 & $1.63 \mathrm{D} \pm 2.22$ & 0.03 & 9.30 & $\mathrm{P}<0.001$ \\
\hline Lead(mg/l) & $0.83 \mathrm{~B} \pm 0.39$ & 0.10 & 2.0 & $1.01 \mathrm{~A} \pm 0.4$ & 0.10 & 1.80 & $0.69 \mathrm{C} \pm 0.26$ & 0.10 & 0.99 & $0.86 \mathrm{~B} \pm 0.35$ & 0.12 & 1.38 & $0.61 \mathrm{C} \pm 0.36$ & 0.10 & 1.60 & $\mathrm{P}<0.01$ \\
\hline Cadmium(mg/l) & $0.05 \mathrm{~B} \pm 0.16$ & 0.00 & 0.81 & $0.51 \mathrm{~A} \pm 0.52$ & 0.00 & 2.01 & $0.08 \mathrm{~B} \pm 0.08$ & 0.00 & 0.30 & $0.42 \mathrm{~A} \pm 0.45$ & 0.0 & 1.15 & $0.07 \mathrm{~B} \pm 0.06$ & 0.00 & 0.24 & $\mathrm{P}<0.001$ \\
\hline
\end{tabular}

Similar letters indicate means that are not significantly different from each other

Note: $\mathrm{P}<0.001 ; \mathrm{P}<0.01$-Highly Significant; $\mathrm{P}<0.05$ - Significant; $\mathrm{P}>0.05$ - Not Significant 
Table 2. Test of significant difference between the dry and wet season of physico-chemical parameters

\begin{tabular}{|c|c|c|c|}
\hline PARAMETERS & $\begin{array}{c}\text { DRY SEASON } \\
\bar{x} \pm \text { SD } \\
\end{array}$ & $\begin{array}{c}\text { WET SEASON } \\
\bar{x} \pm \text { SD }\end{array}$ & SIGNIFICANCE \\
\hline Air Temp $\left({ }^{\circ} \mathrm{C}\right)$ & $29.63 \pm 2.87$ & $31.18 \pm 2.82$ & $\mathrm{P}<0.01$ \\
\hline Water Temp $\left({ }^{\circ} \mathrm{C}\right)$ & $28.48 \pm 3.91$ & $29.88 \pm 2.62$ & $\mathrm{P}<0.05$ \\
\hline Depth (m) & $4.33 \pm 1.72$ & $5.45 \pm 2.11$ & $\mathrm{P}<0.001$ \\
\hline TDS (mg/l) & $169.9 \pm 88.5$ & $202.5 \pm 103.9$ & $\mathrm{P}<0.001$ \\
\hline $\mathrm{TSS}(\mathrm{mg} / \mathrm{l})$ & $72.78 \pm 28.28$ & $97.05 \pm 57.2$ & $\mathrm{P}<0.001$ \\
\hline Total Solid (mg/l) & $242.4+115.1$ & $29.6 \pm 153.6$ & $\mathrm{P}<0.001$ \\
\hline Water current $(\mathrm{cm} / \mathrm{s})$ & $23.1 \pm 4.88$ & $28.23 \pm 8.3$ & $\mathrm{P}<0.001$ \\
\hline Transparency $(\mathrm{cm})$ & $80.28 \pm 25.84$ & $102.9 \pm 30.93$ & $\mathrm{P}<0.001$ \\
\hline $\mathrm{pH}$ & $6.89 \pm 0.95$ & $6.86 \pm 0.83$ & $\mathrm{P}>0.05$ \\
\hline $\mathrm{DO}(\mathrm{mg} / \mathrm{l})$ & $6.49 \pm 1.99$ & $6.77 \pm 1.85$ & $\mathrm{P}>0.05$ \\
\hline $\mathrm{BOD}(\mathrm{mg} / \mathrm{l})$ & $4.699 \pm 1.41$ & $4.43 \pm 1.59$ & $\mathrm{P}>0.05$ \\
\hline Conductivity $(\mu \mathrm{S} / \mathrm{cm})$ & $98.6 \pm 13.96$ & $128.6 \pm 33.29$ & $\mathrm{P}<0.001$ \\
\hline Total Alkalinity(mg/l) & $29.78 \pm 6.97$ & $38.34 \pm 10.28$ & $\mathrm{P}<0.001$ \\
\hline Phosphate(mg/l) & $0.33 \pm .119$ & $0.37 \pm 0.151$ & $\mathrm{P}>0.05$ \\
\hline Nitrate(mg/l) & $2.65 \pm 1.32$ & $0.76 \pm 0.89$ & $\mathrm{P}<0.001$ \\
\hline Lead(mg/l) & $0.69 \pm 0.31$ & $0.91 \pm 0.41$ & $\mathrm{P}<0.01$ \\
\hline Chromium(mg/l) & $0.13 \pm 0.22$ & $0.11 \pm 0.13$ & $\mathrm{P}>0.05$ \\
\hline Copper(mg/l) & $0.56 \pm 0.25$ & $0.78 \pm 1.11$ & $\mathrm{P}>0.05$ \\
\hline $\operatorname{Zinc}(\mathrm{mg} / \mathrm{l})$ & $3.28 \pm 2.29$ & $3.03 \pm 2.29$ & $\mathrm{P}>0.05$ \\
\hline Cadmium(mg/l) & $0.17 \pm 0.30$ & $0.28 \pm 0.42$ & $\mathrm{P}>0.05$ \\
\hline Magnesium(mg/l) & $3.87 \pm 2.08$ & $3.79 \pm 2.02$ & $\mathrm{P}>0.05$ \\
\hline Sulphate(mg/l) & $0.32 \pm 0.13$ & $0.35 \pm 0.08$ & $\mathrm{P}>0.05$ \\
\hline Calcium(mg/l) & $1.3 \pm 0.58$ & $1.83 \pm 0.72$ & $\mathrm{P}<0.001$ \\
\hline $\mathrm{CO}_{2}(\mathrm{mg} / \mathrm{l})$ & $2.97 \pm 0.49$ & $2.75 \pm 0.41$ & $\mathrm{P}<0.05$ \\
\hline Potassium(mg/l) & $0.65 \pm 0.22$ & $0.70 \pm 0.20$ & $\mathrm{P}<0.05$ \\
\hline Sodium(mg/l) & $0.88 \pm 0.23$ & $2.05 \pm 7.61$ & $\mathrm{P}>0.05$ \\
\hline
\end{tabular}

Note: $\mathrm{P}<0.001 ; \mathrm{P}<0.01$-Highly Significant; $\mathrm{P}<0.05$ - significant; $\mathrm{P}>0.05 \quad$-Not significant

The BOD ranged from 1.8 (station 5) to 9.5 (stations 1). Analysis of spatial difference using One Way ANOVA revealed highly significant difference $(\mathrm{P}<0.01)$. A posteriori Duncan Multiple Range Test showed that BOD was significantly higher in stations 1 and 2 than the other stations, and significantly lowest in station 5. Seasonal analysis (Table 2) showed higher BOD in the dry than in the wet season, but the difference was not significant $(\mathrm{P}>0.05)$. DMR test shows that station 5 had the lowest conductivity and it is significant.

Conductivity was relatively low, ranging from 63.3 in station 3 to $190 \mu \mathrm{S} / \mathrm{cm}$ in stations 2 . The analysis of variance showed a highly significant $(\mathrm{P}<0.01)$ difference in the conductivity across the 5 stations, with significantly higher values in stations 2 and 3, and lowest value in station 5 . The mean value of conductivity was higher in wet season $(128.6$ $\pm 33.29 \mu \mathrm{S} / \mathrm{cm})$ than the dry season $(98.6 \pm 13.96 \mu \mathrm{S} / \mathrm{cm})$ (Table 2).

Total Alkalinity ranged from 19.5 in station to 1 to 40.1 $\mathrm{mg} / \mathrm{l} \mathrm{CaCO}$ in station 5 . The analysis of variance showed a highly significant difference $(\mathrm{P}<0.01)$ in the alkalinity across the stations. Alkalinity was significantly higher in stations 2 and 3 than the other stations. The mean value for Alkalinity was higher in wet $(38.34 \pm 10.28)$ than in the dry $(29.78 \pm$ 6.97) season. DMR test shows that station 5 with the lowest alkalinity is significantly different from stations 2 and 3; 4 and 1 , respectively.

In all the stations, free $\mathrm{CO}_{2}$ ranged from 1.80in station 3 to $4.22 \mathrm{mg} / \mathrm{l}$ in Station 1. The analysis of variance showed a significant difference $(\mathrm{P}<0.01)$ in free $\mathrm{CO}_{2}$ across the stations, and the a posteriori test revealed that station 5 had significantly lower value than the other stations. The mean value for free $\mathrm{CO}_{2}$ was higher in the dry than in the wet season (Table 2).

In all the stations, sulphate ranged from 0.18 in station 3 to $0.98 \mathrm{mg} / \mathrm{l}$ in station 2 . The analysis of variance shows highly significant difference $(\mathrm{P}<0.001)$ in sulphate across the 5 stations. DMR test shows that station 3 had the lowest sulphate level and it was significantly different from the higher values in stations 2 and 1; 5 and 4, respectively. The 
mean value of sulphate was higher in wet season than in the dry season (Table 2).

Nitrate ranged between 0.10 (station 4) to 5.46 $\mathrm{mg} / \mathrm{l}$ (station 3). Analysis of variance showed no significance $(\mathrm{P}>0.05)$ across the 5 stations (Table 1$)$. Nitrate was higher in dry than wet season (Table 2).

Phosphate ranged from 0.18 (stations 4 and 5) to 0.9 $\mathrm{mg} / 1$ (stations $1,3,4)$. The analysis of variance showed highly significant difference $(\mathrm{P}<0.01)$ in the phosphate across the five stations. DMR test showed that station 5 recorded the least phosphate level and it is significantly different from stations 3 and 4; 1 and 2, respectively. The mean value of phosphate was higher in wet season than dry season (Table 2).

According to your Table 1 , the next is sodium, then potassium, calcium etc before chromium.

Please you must prove to me that you understand your own thesis by re-writing this paper following my example. Am not impressed! If you don't go this way, you can never stand on your own to defend your doctorate. My sincere promise was to make sure you have a $\mathrm{PhD}$, but you have to wake up to defend it, at least before me. Re-write this like a $\mathrm{PhD}$ holder and let me have it. Otherwise you have to come to Benin to spend some time for further mentoring to be able to defend your title.

In all the 5 stations, sodium ranged from 0.6 in station 5 to $1.12 \mathrm{mg} /$ lin station 1 . The analysis of variance shows no significant $(\mathrm{P}>0.05)$ difference across the 5 stations. The mean value of sodium was higher in wet than dry season (Table 2).Potassium ranged from 0.10 in station 4 to 1.30 $\mathrm{mg} / \mathrm{l}$ in station 2 . The analysis of variance shows highly significant $(\mathrm{P}<0.001)$ difference in potassium across the 5 stations. DMR test showed that stations 2,3 and 1 respectively were higher in potassium level than stations 4 and 5. The mean value of potassium was higher in wet than dry season (Table 2).

In the same vein, calcium values across the 5 stations ranged between 0.38 (station 4) and $3.2 \mathrm{mg} / \mathrm{l}$ (station 2). Analysis of variance showed that the means were highly significant $(\mathrm{P}<0.001)$ across the 5 stations (Table 1$)$. Duncan Multiple Range (DMR) showed that stations 2 and 3 were significantly higher than stations 1,4 and 5 . Calcium value was higher in wet than in dry season (Table 2).

In all the 5 stations, magnesium ranged from 1.0 (stations 4 and 5) to $9.99 \mathrm{mg} / 1$ (station 5). The analysis of variance showed no significant difference $(\mathrm{P}>0.05)$ in the magnesium across the 5 stations. The mean value of magnesium was higher in dry than wet season (Table 2).

Chromium ranged from 0.00 to $1.00 \mathrm{mg} / \mathrm{l}$, with the highest value recorded in stations 4 and 5 . The analysis of variance shows no significant difference $(\mathrm{P}>0.05)$ across the five stations. The mean value of chromium was higher in dry season than wet season (Table 2).

In all the five stations, copper ranged from 0.06 (station 1) to $9.0 \mathrm{mg} / \mathrm{l}$ in station 2 . The analysis of variance showed that the values were highly significantly different $(\mathrm{P}<0.01)$ across the 5 stations. DMR test shows that station 2 with the highest copper concentration is significantly different from the other stations. The mean value of copper was higher in dry season than wet season (Table 2).

Spatially, zinc ranged from 0.03 in station 5 to $9.45 \mathrm{mg} / \mathrm{l}$ in station 4. Analysis of variance showed that the means were highly significantly different $(\mathrm{P}<0.001)$ across the five stations. DMR test showed that stations 2 and 3 were significantly higher than the other stations. The mean value of zinc was higher in dry season than wet season (Table 2).

Lead ranged from 0.10 in stations $2-5$, to $2.0 \mathrm{mg} / \mathrm{l}$ in station 1 . The analysis of variance showed highly significant difference $(\mathrm{P}<0.01)$ across the five stations. DMR test showed that station 2 with the highest lead concentration is significantly different from the other stations. The mean value of lead was higher in wet season than dry season (Table 2).

Spatially, cadmium ranged from 0.00 in station $1,2,3,5$ to 2.0 in station 2 . The analysis of variance shows no significant ( $\mathrm{P}>0.01)$ difference in the cadmium across five stations. DMR shows that stations 2 and 4 showed the highest concentration of cadmium when compared to station 3,5 and 1 respectively. The mean recorded value for cadmium was higher in wet than dry season (Table 2).

\section{Discussion}

Earlier reports on the variation in physical and chemical hydrology of tropical water bodies showed changes between samples, stations and seasons (Beadle 1981; Odum, 1992). These reports stated that climatic conditions like radiation, ecological conditions, concentration of organic matter and other relation of forces are some of the factors governing these variations. In this study, there were temporal variations in both water and air temperature in the five stations. This observation is similar to observations earlier made by Awachie (1981), Chapman and Kramer (1981) and Ogbeibu and Victor (1995) who asserted that the temperature of surface water follows the ambient temperature. This ambient temperature is be influenced by the composition of substrate, turbidity, vegetation, and surface run - off and heat exchange with the air. The present result $(20-36.30 \mathrm{C})$ is slightly higher than the limit of $350 \mathrm{C}$ stipulated by Federal Ministry of Environment (FMEnv). However, this could be caused primarily by the degree of exposure of the station to sunlight, period (time) of sampling and human activities (Alabaster and Lioyd, 1980). Total dissolved solids (TDS), total suspended solids (TSS) and total solid (TS) were higher in wet than in dry season due to the large array of human activities (stations 2, 3 and 4). These activities include domestic waste deposits by the riverside, industrial effluents and run -offs into the river from the catchments stretch.

These parameters, TSS, in particular are variable and determine the transparency of a water body (Booth, 2005). The range of TDS in the present study (60 to $471 \mathrm{mg} / \mathrm{l}$ ) agrees closely with the finding of Omoigberale and Ogbeibu (2005) in Osse River (42.5- $456 \mathrm{mg} / \mathrm{l}$ ) whereas, the TSS of 
the present study $(40-260 \mathrm{mg} / \mathrm{l})$ is higher than that of Osse River (14.66 -210 mg/l). The flow velocity was higher in wet season while station 1 (close to the Niger Bridge) and station 4 (influenced by the in- let of Nkisi stream), depicted higher values. Fluctuations in water level are usually associated with rainfall frequency. Transparency which is literally translated as water clarity is an important property of water related to productivity. This physical property is strongly affected by the materials suspended and dissolved in water. The present study with highest transparency at the less perturbed stations 1 and 5 agrees with the assertion of Huber and Castro(2005), that transparency is higher in dry season due to absence of surface run-offs. Effect of photosynthetic activities on transparency was also observed in the present study as in Baijol et al. (1997). pH determines the nature of $\mathrm{CO}_{2}$ in water. Free $\mathrm{CO}_{2}$ is acidic $\mathrm{pH}$ while carbonates and bicarbonates are in alkaline $\mathrm{pH}$. However, increased $\mathrm{pH}$ favours fish production and portrays the stretch of study as favourable for fish. This report falls within the result range (6.5-9.0) of Boyd and Lichtkopler(1997). Also, the value of free $\mathrm{CO}_{2}$ was lowest in station 5 with the highest $\mathrm{pH}$ value. The $\mathrm{pH}$ of 5.30(station 5) is outside the FMEnv limit of 6.5-8.5. This is an indication that the station will favour more fish catches than others. Similar high values of $\mathrm{pH}$ (Alkaline) are at stations 2 and 4 that have high organic matter from allochtonous and autochthonous sources. There were negligible differences in $\mathrm{pH}$ values of the dry months (6.89) and the wet months (6.86), so the decomposition of litters, mineralization and concentration of salt in the dry season had little effect in this water. This in addition, could be linked to the steady distortion/perturbation around the catchments areas of the study stations. However, this inherent benefit should not overwhelm the many limitations due to human activities. Dissolved oxygen (DO) of this stretch of River Niger is higher in rainy season when there was more mixing of water. The reports (4.4 to 11.6) from Osse River (Omoigberale and Ogbeibu, 2005) is lower than the present study (9.15 to 14.1). It can then be adduced that the in-situ primary production from algae and water plants at bank root and submerged-macrophyte portions of the stations; resulted to varied degrees of increased DO. The low values of oxygen recorded at stations 2,3 , and 4 could probably be as a result of intensive commercial sand offloading activities / substrate perturbations (plates 2, 3, 4). By implication, generally, River Niger at Onitsha is rich in dissolved Oxygen.

BOD is the amount of $\mathrm{O}_{2}$ needed by the microorganisms to effectively decompose organic matter within the medium. The present study agrees with other authorities that higher values were obtained in the dry than wet season. It is also higher in non-organically polluted area. This becomes more pronounced when the amount of inherent organic wastes/matters exceed the thresholds of oxygen needed for decomposition. Hence, stations 1 and 5 showed lower values of BOD and this is in line with the fact that they are less organically polluted. Conductivity is a measure of total ionic composition of water favourable to fish. It helps in maintaining the $\mathrm{pH}$ by buffering the effect as determined by the levels of magnesium, calcium, sodium in the water. This latter relationship is observed at stations 2 (with highest conductivity and calcium respectively). The highest conductivity of this station also favoured its zooplankton and benthos richness as indicated in the Margalef's Index of species-richness. Thus, if the present conductivity potential of station 2 is controlled from perturbations, then it can have more fishes coming for food at its banks. The present study similarly agrees with report of Walsh et al (2008) that conductivity value is higher in dry than wet season. Alkalinity is a measure of weak acid and weak salts in water. Being higher in wet season in the present study is contrary to reports in Walsh et al, (2008) that there is concentration of salt due to evaporation, decomposition and mineralization of litters, during dry season. Therefore, it could be attributed to the perturbations militating against the afore-mentioned processes (Baijot,etal1997;Walsh,etal2008).

Nitrate and Phosphate are indicators of organic pollution. Although highest in stations 2 and Station 3, both also reflected in other stations with submerged macrophyte portions (stations 1, 4, 5), decomposition of raw human sewage washed into the water (Station 2, 3), vegetables and agro decomposition (Station 3), and water run-offs from overlying cow dung deposit (station 4); all showed different concentrations of Nitrate and Phosphate. Other authors with related ranges in their reports of the two indices are (Egborge, 1970, 1971) for River Osun, Ogbeibu and Victor (1995) for Okomu Forest Reserve, Sanctuary, and Holden and Green (1960) for River Sokoto. The highest phosphate levels (Stations 1,3,4) of the present work agree with the work of Hynes (1970), that soaps and detergents used in bathing and other laundering activities are important sources of phosphate. Sodium, Potassium, Calcium as cations are higher in wet season as observed in the present study, due to water dilution and constant utilization by plants. However, sodium is usually higher than potassium due to its retention by living organisms. The values of sodium in the present work can be best described as incidental ( 0.1 to 1.61 at station 3 only). Potassium in the present study (at Onitsha stretch) of River Niger (0.1 to 1.3) is quite low compared to Osse River (1.0 to 9.6) by Omoigberale and Ogbeibu (2005); and Holden and Green(1960) for River Sokoto. Chromium, Copper, Zinc, Lead and Cadmium (the afore- mentioned heavy metals) are also known to have densities 5 times greater than water (Garbarino et al., 1995).Similarly Zinc (station 4) and cadmium (station2) were extremely high in the Onitsha stretch of River Niger. The high level of lead at station 1 (with less perturbation) could be attributed to rusted abandoned- metallic body ships/machineries formerly used by the old Federal Inland Water ways, whose Base is by the station. The Principal Component Analysis(PCA) from the River Niger study area at Onitsha showed that domestic 
waste discharge, industrial waste discharge, total solids and bio-degradable organic matters are the main causes of variations in water quality in that region. The weak correlation of some of the fauna to water quality parameters can be attributed to their physiological adaptations to the unfavourable environmental conditions and this agrees to the opinions of works as in Ajao and Fagade (1990), Ogbogu(2001) and Tjokunburi et al. (2002).

\section{Conclusion}

The reports from this study serve as a baseline pre-dredging water quality data of this axis of river Niger at Onitsha. Hence, efforts to minimize or eradicate the adverse effects of human perturbations and dredging on the water quality and biota of this study area will be intensified by relevant agencies. This will bring forth an aesthetically/economically improved river port along this Onitsha urban shelf of river Niger.

\section{REFERENCES}

[1] Adebisi, A.A. (1981): The physico-chemical hydrology of tropical seasonal river - upper OgunRiver. Hydrobiologia 79: 159-165.

[2] Ajao,E.A. and Fagade, S.O (1990): A study of sediment communities in Lagos Lagoon, Nigera.J.Oilchem.. pollut 7:85 105 .

[3] Akpan, E.R. (1998): Possible environmental impact of channelization and dredging on the ecologyof the Cross River Estuary System-Nig: Tropical Fresh Water Biol. 7: 53-16.Alabaster, J.S and Lyoyd, R (1980): Water quality criteria for fresh water fish 2nd Ed. Butter Worth's,London,361pp.

[4] APHA (1985): American Public Health Association. Standiard methods for the examination of water and waste waters. 16th Edn. Washington D.C. 1268pp.

[5] APHA (1998): American Water Works \& Water Pollution Control Federation. Standard methods for the examination of water \& waste water. 20th Edn

[6] Awachie, J.B.E. (1981): Running water ecology of Africa. In perspectives in water ecology Ed. by M.A. Lock \&D.D. Wllliams. PP 339-.366 New York, Plan press.

[7] Baijot, E. Moreau, J. and Bouada Sana (1997): Hydrobiological aspects of fisheries in Sahel Region.Technical Center forAgricultural \& Rural Co-operation. ACP - EU. 220pp.

[8] Beadle, L.C. (1981): The inland waters of tropical Africa. An Introduction of tropical limnology.Longman Press Ltd. London.

Booth, D.B. (2005): Challenges \& prospects for restoring urban streams: A perspective from the Pacific North-West of North America. Journalof Benthological Society, 24(3): 724 $-137$.
[9] Boyd, C.E. (1979): Water quality in warm water fish pond. Craft Master print Inc.Auburn, Alabama. Pp 353.

[10] Castro, P. and Huber, M.E. (2005): 1997, Water transparency; Marine Biology, $5^{\text {th }}$ Edition. Pp 40-49.

[11] Chapman, L.J and Kramer, D.C (1981): Limnoloical observations of intemittent of tropical dry forest stream. Hydrobiology, 226: 153-166.

[12] Egborge, A.B.M. (1979): The effect of impoundment on the water chemistry of lake Asejire,Niger freshwater Biol. 9: 403 - 12.Egborge, A.B.M \& Sagay, E. (1979): The distribution of phytoplankton and zooplankton in some lbadan water bodies.Arch. Hydrobiologia. 26(2): 189-202.Egborge, A.B.M, Onwudinjo C.C \& Chigbu, P.C. (1994): Cladocera of coastal rivers of Western Nigeria. Hydrobiologia, 272: 39-46.

[13] Gleick, P.H. (2008): The world's waters, biennial report on fresh water resources Washington, Island Press (Nov. 10, 2006).

[14] Gonzalez, J.A (1997): Seasonal variation in the foraging ecology of the wood stork in the Southern Venezuela. Limnolcgy and Oceanography, 4:15-20.

[15] Henderson-Sellers, A. \& Gornitz, V. (1984) Possible climate impact of land cover transformationwith particular emphasis on tropical deforestation. Climatic Change 6, 231-258.

[16] Holden, M. J. L. \& Green, J. (1960): The hydrology and plankton of the, River Sokoto. J. Anim.Ecol.29:65-84.

[17] Hynes, H. B. N (1970): The ecology of running waters. University of Toronto Press.

[18] Karpuruzcu, M. \&Senes.S.(1987): Design of monitoring Systems for water quality by principal component Analysis and a case study". Proceedings of the International Symposium OnEnvironmental Management. Environment ${ }^{\circ} 87$ vol1. 673-690- Instanbul.

[19] Krest, C. D \& Anderson N. H (1975): The plecoptera community of a small stream in Oregon U.S.A. Freshwater Biol: 5:189-203.

[20] Lind, O.T. (1974): Handbook of common method in limnology. The C.V. company, Saint. Louis. Pp. 154.

[21] Magurran, A. (1988): Ecological Diversity and its measurements, London,Croom Helm

[22] Odum, E.P. (1959): Fundament ecology 2nd Edition. W.P. Sander Philadelphia and London PP 546.

[23] Odum, O. (1992): The ecology \& biology of the fishes of Ethiope river, Nig. Ph.D Thesis, UniversityofBenin,BeninCity,Nip.222Pp.

[24] Odunuga,S.,Tejuoso,O. and Mayowa, F. (2003): Cumulative environmental change in the lower Niger. Proceedings of symposium HS02a held during IUGG2003 al Sapporo.IAHS Publ. no. 280.Pg221.

[25] Ogbeibu, A.E. (1987): The effect of road and bridge construction on the macrobenthic invertebrates of the lkpoba River, Benin City, Nig. 233pp.

[26] Ogbeibu, A.E. (2001):Distribution , density and diversity of dipterans in a temporary pond inOkumu Forest Reserve Southern Nigeria, Tropical Ecology 42(2), $259-268$. 
[27] Ogbeibu, A.E. \& B J. Oribhabor (2002): Ecological impact of river impoundment using benthic macroinvertebrates as indicators. Water Res 36: 2427-2436.

[28] Ogbeibu, A.E. \& Victor R. (1989): The effects of road and bridge construction on the bank-root macroinvertebrates of a southern Nigeria stream. Environ. Pollut 56:85-100.

[29] Ogbeibu, A.E \& Victor R. (1995): Hydroblological studies of water bodies in Okomu forest reserve (Sanctuary): In southern Nig. 1. Distribution \& diversity of the invertebrate fauna. Tropical Fresh water Biology. 4: 1-19.

[30] Ogbogu, S.S. (2001): Assessment of water quality and macroinvertebrates abundance in Opa-stream Reservoir system, Ile Ife. Glob,J. Pure Appl. Sci 17 (3): 517-521.

[31] Omoigberale, M.O and Ogbeibu, A.E. (2005): Assessing the environmental impacts of oil explorationand production on the Osse River, southern Nig: 1 Heavy metals. African Journal of Environment Pollution and Health, 4(1): 27-32.

[32] Rosenberg, D.M. andV. Roth (1993): Introduction to fresh water biomonitoring and benthic macroinvertebrates in freshwater biomonitoring and benthic macro-invertebrates, Rosenberg, D. M. And V. H. Resh (Eds) Chapman and Hall, New York, ISBN. 0412022516.Pp: 1-9.

[33] Schetagne, R.(1985): "The use of Multivariate methods in theinterpretation of Water quality monitoring data of a large
Northern Reservoir." Proceedings of the work-shop held at the Canada centre for Inland waters. Edited by A.H.EL-SHARARAWI-R-EKWIATKOWSKI.Statistical aspects of water quality monitoring 31-43.

[34] Swingle, H.S. (1999): Method of analysis of water organic matter and pond bottom soil, used in fisheries research. Auburn University, PP 1-118.

[35] Taylor D.J. (2000): Aquatic habitat - Fresh water ecosystem, biology 3rd edition Cambridge University Press. Pp 321-324.

[36] Tyokumburi, E.T Okone T.C and Ugwumba, O.A (2002) Limnological assessment of the effects of effluents on macroinveitebrate fauna in Awba stream and reservoir, Ibadan Nigeria The Zoologist1(2): 50-69.

[37] Walsh, C. J. T. D. FletcherandA. R. Ladson (2008): Stream restoration in urban catchments through redesigning storm water systems: Looking to the catchments to save the stream. Journal of the North American BenthologicalSociety. 24: 690-705.

[38] Wetzel, R.G. (1990): Limnology, 2nd Edition C.B College Pase Saunder PP 743

[39] Williams, D.D. (1980): Temporal patterns in recolonization of stream benthos. Arch Hydrobiol. 9(1):56-74.

[40] Zar, J.H. (1984): Biostatistical analysis. $2^{\text {nd }}$ edition Prentice Hall, New Jersey. 718pp. 